\title{
Towards Prevalence of Negeri Sembilan Malay Traditional Architecture for Future Communities: Misconceptions
}

\author{
Mawar Masri \\ Faculty of Architecture, Planning and Surveying, Universiti Teknologi MARA, \\ Shah Alam, 40450, Selangor D.E., Malaysia \\ mawar_masri@yahoo.com
}

\begin{abstract}
Negeri Sembilan's unique identity is facing gradual disappearance endangering future generation's identity's ownership as well as cultural and built environment quality due to such misconception. This paper seek to present the findings of a comprehensive literature reviews which then tested by a perception survey. The literature review is part of the research activities aimed in unravelling the authenticity of Negeri Sembilan traditional houses. The research methodology was qualitative. This paper enables understanding of apparent misconception and an important milestone on an ongoing research towards preserving the Negeri Sembilan architectural identity for our future communities in facing environmental challenges.
\end{abstract}

Keywords: Negeri Sembilan traditional architecture; misconception; identity ownership; future communities.

eISSN 2514-751X @ 2018. The Authors. Published for AMER ABRA cE-Bs by e-International Publishing House, Ltd., UK. This is an open-access article under the CC BY-NC-ND license (http://creativecommons.org/licenses/bync-nd/4.0/). Peer-review under responsibility of AMER (Association of Malaysian Environment-Behaviour Researchers), ABRA (Association of Behavioural Researchers on Asians) and cE-Bs (Centre for EnvironmentBehaviour Studies), Faculty of Architecture, Planning \& Surveying, Universiti Teknologi MARA, Malaysia.

https://doi.org/10.21834/aje-bs.v3i8.289 


\subsection{Introduction}

This paper seek to present the findings of a comprehensive literature reviews as part of the research activities aimed at determining the authenticity of the Negeri Sembilan traditional architecture. The research was proposed when Malaysia's identity for booth design at the Shanghai World Expo 2010 was represented by Minangkabau identity, a community from the West Sumatra in Indonesia. A misconception emerged from misapprehension of the history of South-East Asia. The findings are aimed to clarify the facts and re-oriented the architectural interpretation within the local context, not meant to deny the Minangkabau influence that have evolved together within the local communities.

The Nara Document of Authenticity 1994, stated, heritage of all cultures and societies are rooted in the particular forms and means of tangible and intangible expression. Subsequently, our future communities' identity is undeniably reflected in our heritage, especially the built heritage, measured as a reflection of the community's socio-cultural identity. Placing in the Negeri Sembilan context, the prevalence of their architectural identity is dependent on the degree of understanding of both communities' historical relationship. Within a scope of a single paper it is not possible to describe in detail the historical relationship between Negeri Sembilan and Minangkabau communities. Rembau district was chosen due to many significant historical events of Negeri Sembilan occurred there. Contextual understanding of the history and location however is vital in order to comprehend this paper. Therefore for further understanding of the historical and geographical relationships as well as the significance of research site see Masri et. al (2012a). Refer also to Figure 2, 3 and 4 for an overview of the historical settings (adapted from Masri et. al., Loeb, Kato and Asri).

\subsection{Research Site}

Rembau is a district in Negeri Sembilan, a state in Malaysia located on the central west coast on the Malay Peninsula. Refer to Figure 1(a) and 1(b).

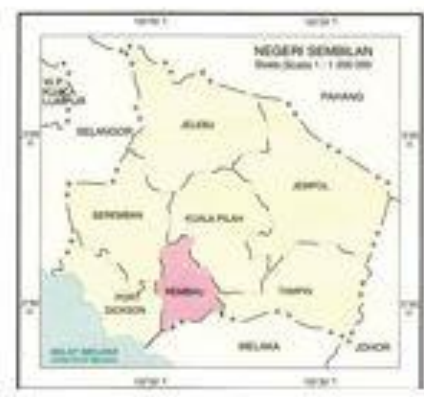

(a)

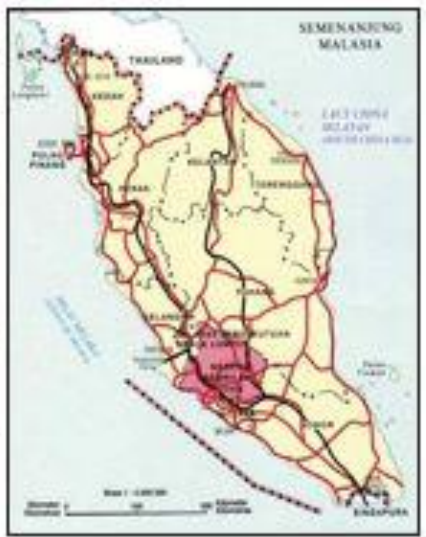

(b)

Fig. 1: (a) Location of Rembau; (b) Location of Negeri Sembilan (JUPEM, 2006). 


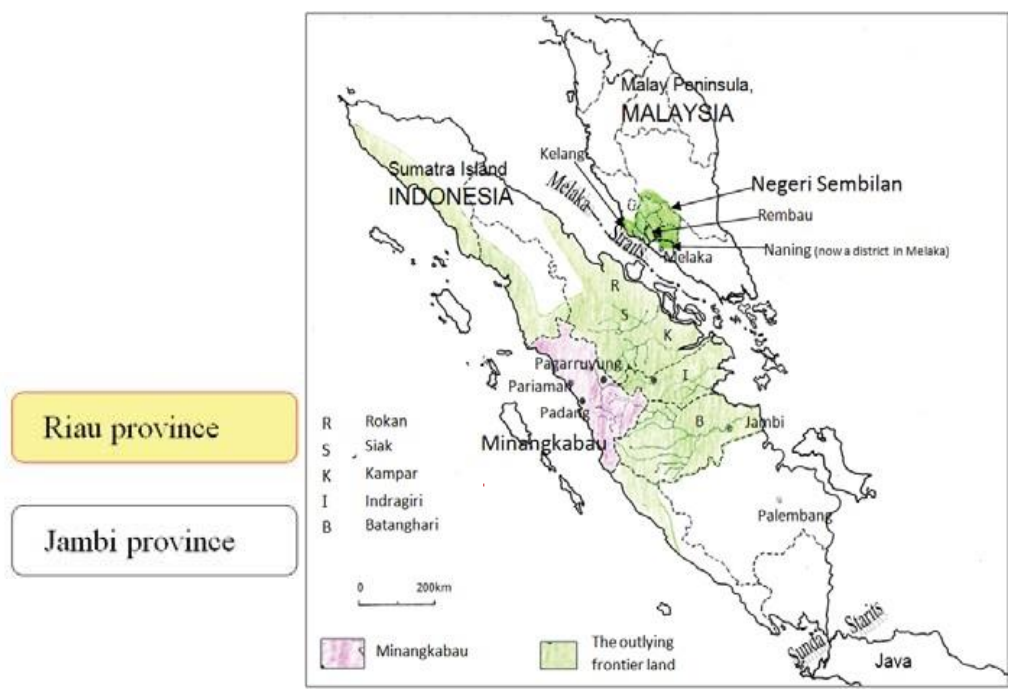

Fig. 2: Show the extent of Minangkabau kingdom at its peak.

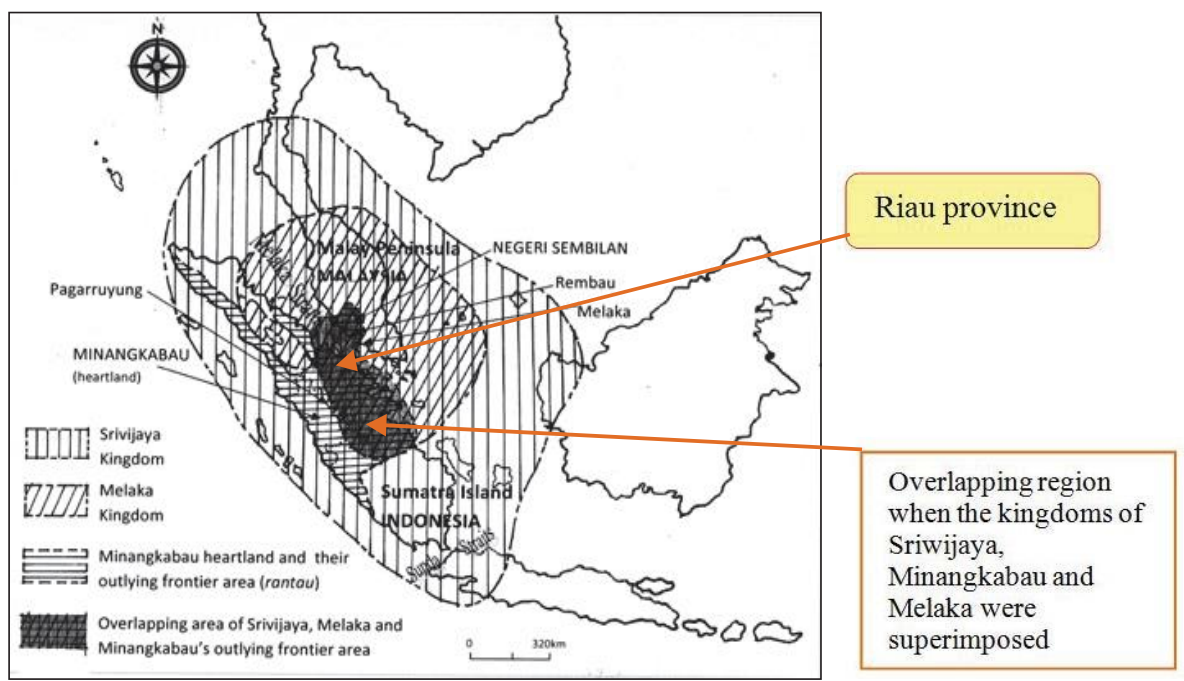

Fig.3:MapshowingtheoverlappingareathatwascommontotheSriwijaya,Melaka and Minangkabau Kingdoms 
TheNegeri Sembilan land from Sriwijaya,

Pagarruyung, Minangkabaul, Melaka andJohor-Riaul.

Noteall the rise and fall of the ancient Malay kingdoms within this timeline, highlighted by the grey band.

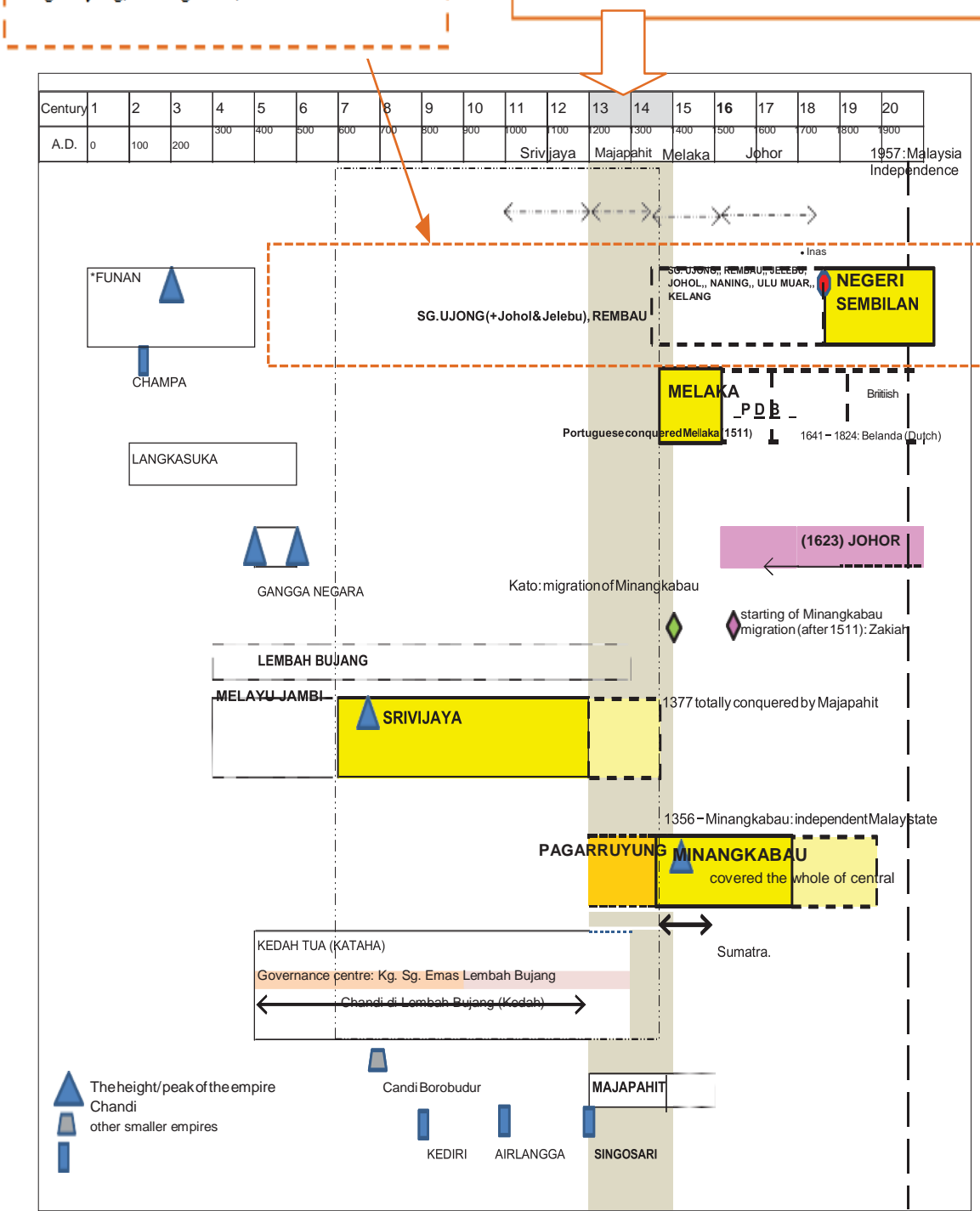

Fig. 4: Timeline of the Ancient Malay Kingdoms from $1^{\text {st }}$ to $19^{\text {th }}$ Century. 


\subsection{Negeri Sembilan's Ruling System}

Adat Perpatih is name given to the present matrilineal practices in Negeri Sembilan, believed to be originated from Minangkabau (Gullick, 2003; Ahmat, 2010).

Ideally there were 12 clans but today there are twenty-seven clans with 20 Clan-chief ('Lembaga') now. The Biduanda clan is the original settlers or the local aborigines in Negeri Sembilan (Ibrahim, 1988; Gullick, 2003; Adil, 1981). Therefore only the male descendants from the female bloodline of the Biduanda clan can be appointed to be the Ruling Chiefas in Figure 5.

\subsection{Methodology}

The overall research methodology is qualitative. The methodology of the research is divided into five phases. The literature reviews are executed at Phase 2 where the secondary data is divided into five categories as shown in Figure 6 which lead to this paper. The survey result will make the conclusion of this paper more robust.

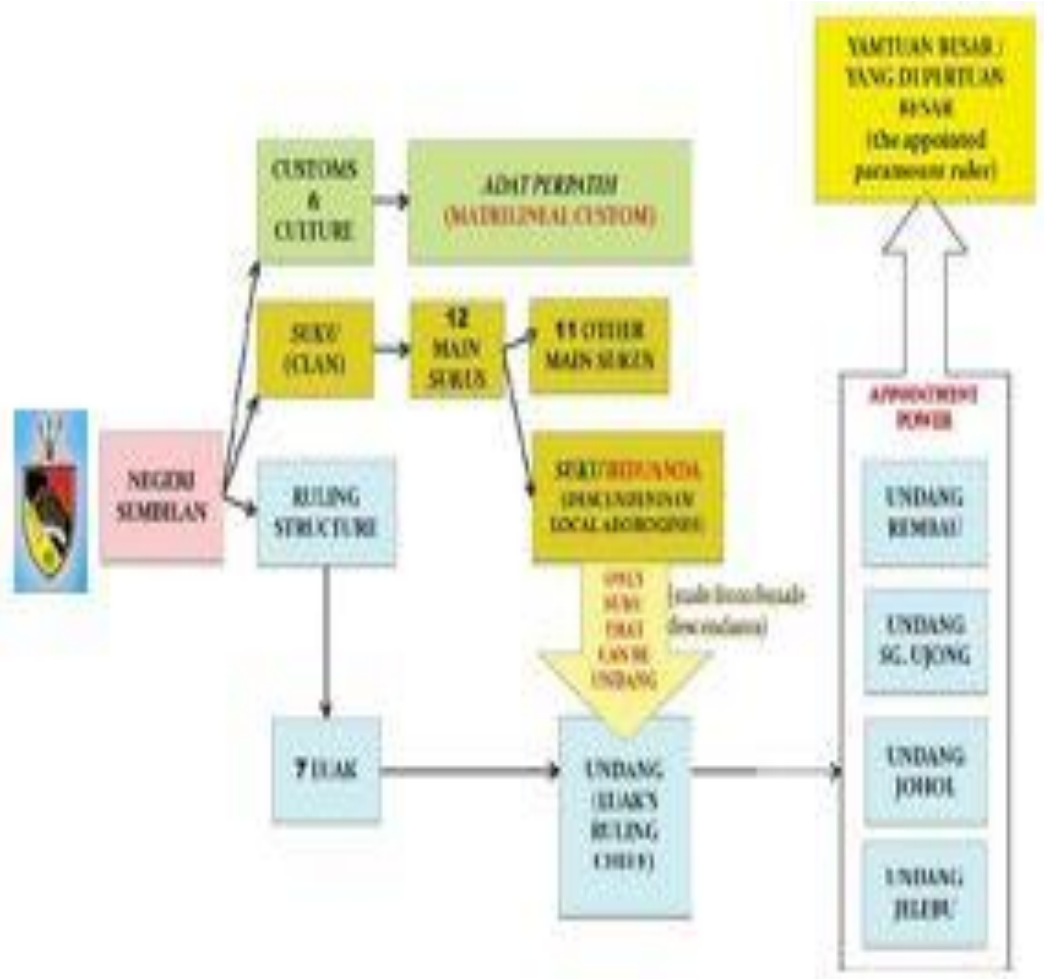

Fig. 5: Illustrate Negeri Sembilan's uniqueness: their customs, clans and ruling structure. 


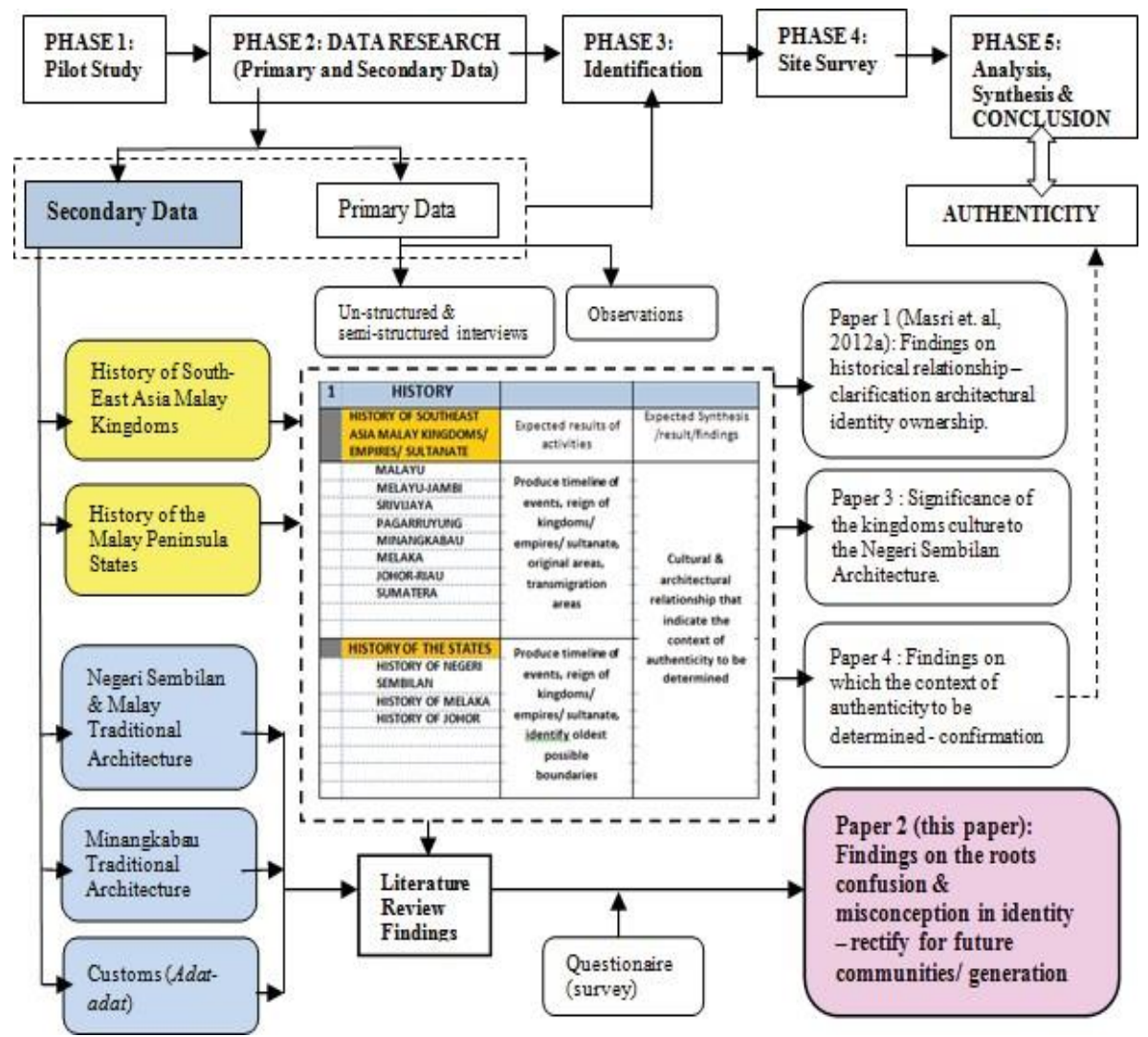

Fig.6: The methods in the literature review research

\subsection{Research Limitations}

The grant scheme only funded research activities with sites only within Malaysia. Comparison with any information gathered about another countries were only through content analysis of the secondary data gathered, the literatures. The findings would be more robust if the study of the Minangkabau traditional architecture could be executed in the Central Western Sumatra.

\subsection{Literature Review Findings}

\subsection{Emergence of the misconceptions}

The roots of the emergence of the misconceptions were mostly in the association with Minangkabau as summarized in Figure 7 based on the preceding paper, Masri et. al, 2012a. 
It should be stressed that these events had indirectly yield certain mistaken believe, especially in the architectural identity. Nonetheless this paper's emphasis is towards the traditional architecture of Negeri Sembilan.

\begin{tabular}{|c|c|c|c|}
\hline HISTORICAL EVENTS & YIELDED MISTAKENBELIEF & CONSEQUENCES & MISCONCEPTIONS \\
\hline $\begin{array}{l}\text { (i) The influantial two major transmigration wavas of } \\
\text { the Minanglkabsus to Remban in Negeri Sembilan } \\
\text { ground 1400 A.D. (Karo, 1997; Iorahim, 1988). First } \\
\text { wave: Southem part (Lotrer) of Remban; Second } \\
\text { waves: Northem part (Upper) of Rembsu. }\end{array}$ & $\begin{array}{l}\text { They were the psople who opened } \\
\text { the settlements in Rembsu } \\
\text { subsequently other minor states. Also } \\
\text { yielded Misconception } 1 \text {. }\end{array}$ & $\begin{array}{l}\text { This belief make most } \\
\text { people believe that both }\end{array}$ & \\
\hline $\begin{array}{l}\text { (ii) Historically Rembsu was achnowledged in tha } \\
\text { literatures as the principle luaks of the nine minor states } \\
\text { in Negeri Sembilan (Gullick; 2003; Idrus, 1996; } \\
\text { Iorakim, 1988; de Jong, 1975). }\end{array}$ & $\begin{array}{l}\text { Imply that, all of the Malays of } \\
\text { Negeri Sembilan are the } \\
\text { Ninanglabasu people from Central } \\
\text { West Sumatra. }\end{array}$ & $\begin{array}{l}\text { including architectural is } \\
\text { the seme, from the aspect } \\
\text { of philosophy, } \\
\text { representation and analogy } \\
\text { in design. }\end{array}$ & $\begin{array}{l}\text { Misconception 1: } \\
\text { The Malays of Negeri Sembilan } \\
\text { originated from the } \\
\text { Minangkabau heartland in } \\
\text { Central West Sumatra. }\end{array}$ \\
\hline $\begin{array}{l}\text { (iii) Tha installation of Raja Melarrar from } \\
\text { Paganyung Royals in Minanglkabsu as the Paramount } \\
\text { Appointed Ruler (Yang DiPertuan Bear or Yamtuan } \\
\text { Bearr) in Negeri Sembilan in 1773 A.D. }\end{array}$ & $\begin{array}{l}\text { their ruler from their orn poople. } \\
\text { This gave the impression implied } \\
\text { that the prople in Negeri Sembilan } \\
\text { originated from Minanglabsu. }\end{array}$ & 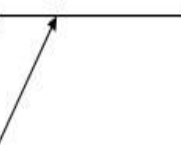 & $\begin{array}{l}\text { Misconception 4: } \\
\text { TheInterior spatial layout } \\
\text { of Negeri Sembilan }\end{array}$ \\
\hline $\begin{array}{l}\text { (iv) The dynamism of tha mritime culture of the } \\
\text { ancient Malay Kingdoms of the Insular Southesst Asia } \\
\text { (Kato, 1997), espacially within and around the Melalsa } \\
\text { Straits. }\end{array}$ & $\begin{array}{l}\text { The old Negeri Sembilan territories } \\
\text { were part of the Minanglisban } \\
\text { outlying frontier ares Therefore the } \\
\text { culture, customs, lifestyle and } \\
\text { achitecture is the same as in the } \\
\text { Minangkabau heartland. }\end{array}$ & & $\begin{array}{l}\text { Traditional houses is the } \\
\text { same as the interior layout } \\
\text { of Minanglkabau traditional } \\
\text { houses. }\end{array}$ \\
\hline $\begin{array}{l}\text { (v) The intemarriages of the Minanghaban lesders and } \\
\text { royals to the daughters of leaders of the aborigines of } \\
\text { Negeri Sembilan that led to the assimilation of the } \\
\text { matrilineal customs from both commurities now hown } \\
\text { as tha 'Adat Perpatih'. }\end{array}$ & $\rightarrow \begin{array}{l}\text { This belief caused psoplet } \\
\text { Minenglisban's people ms } \\
\text { called Adat Perpatih broug } \\
\text { cultural influence on the in } \\
\text { communities' houses is th }\end{array}$ & $\begin{array}{l}\text { that the } \\
\text { ractices was is also } \\
\text { n. Hence the socio. } \\
\text { vut of both }\end{array}$ & $\begin{array}{l}\text { concep tion 2: } \\
\text { Minangkabau people were the } \\
\text { that brought the matrilineal } \\
\text { oms to Negeri Sembilan. It } \\
\text { not rooted from Negeri } \\
\text { bilan land. }\end{array}$ \\
\hline $\begin{array}{l}\text { (vi) The becoming of Pagancyung Kingdom as an } \\
\text { independent Malay state from Majagahit Kingdom, } \\
\text { through a buffalo fight which gave them thename } \\
\text { 'Miranglabsu' replacing 'Pagamuyung' (Loeb, 1989). } \\
\text { The event was reflected in the visual representation of } \\
\text { shape of the roof of their houses, the shape of the }\end{array}$ & $\begin{array}{l}\text { Based on (i), (ii), (iii) and (v), thus } \\
\text { the visual representation of the shape } \\
\text { of the Neger Sembilan houses was } \\
\text { and is presumed to be the same, from } \\
\text { the shape of the 'buffalo homs'. }\end{array}$ & & $\begin{array}{l}\text { Misconception 3: } \\
\text { The upward curre of the Negen } \\
\text { Sembilan roof is the visual analogry } \\
\text { of the buffalo horm. }\end{array}$ \\
\hline
\end{tabular}

Fig. 7: The significant historically event that yielded misconceptions about Negeri Sembilan communities that have significance effects to their architectural identity

Hence the following chapters highlight the literatures in order to resolve the misconceptions.

Misconception 1: "The Malays of Negeri Sembilan originated from the Minangkabau heartland." 
This statement implies as if no local communities exist before the Minangkabau Malays transmigrated. The history books written by Gullick, Adil and Khoo clearly stated the aborigines were in Negeri Sembilan even during the Sriwijaya Kingdoms sovereignty. Astonishingly, some of the architectural books written could mislead readers, indirectly causing misconception as presented in Figure 7 and Table 1.

Table 1: Example some of the written materials from architectural books

\begin{tabular}{|c|c|c|}
\hline $\begin{array}{l}\text { Authort Book } \\
\text { Title }\end{array}$ & $\begin{array}{l}\text { Page } \\
\text { no. }\end{array}$ & Quotations that could mislead \\
\hline Nasir, 1985 & 6 & 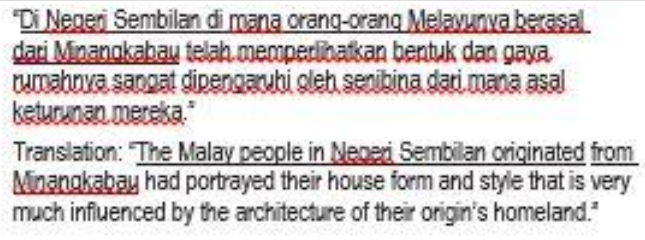 \\
\hline $\begin{array}{l}\text { The } \\
\text { Encyclopedia } \\
\text { of Malaysia: } \\
\text { Architecture }\end{array}$ & 17 & $\begin{array}{l}\text { The roof style of the Mloangkabau-style Negeri Sembilan house ( } 5 \text { ) } \\
\text { is believed to be influenced by the Sumatran house from Indonesia } \\
\text { (6). The ancestors of the people in Neaeri Sembilan came from the } \\
\text { Minarckabau region." } \\
\text { Note: (5) and (6) in the sentence refers to the diagram in the book. }\end{array}$ \\
\hline $\begin{array}{l}\text { The } \\
\text { Encyclopedia } \\
\text { of Malaysia: } \\
\text { Architecture }\end{array}$ & 24 & $\begin{array}{l}\text { "The Negeri Sembilan roof is a visual analogy of a bull's head and } \\
\text { homs, purportedly boncuring the buffalo for the role it plaved in } \\
\text { winning an important battle in Sumatra }\end{array}$ \\
\hline
\end{tabular}

Gullick writing proves the existence of local Negeri Sembilan Malays before the Minangkabau people transmigrated, figured prominently in the Malay legends of their pioneer settlements and the whole area of Naning- Rembau had been occupied by 'aborigines only' when the Portuguese first arrived. Adil's statement further proves the misconception by emphasizing the aborigines of Rembau was unmistakenly the Jakun communities, known as the Biduanda or Mantera people and Sungai Ujong was known to be under the sovereignty of the Sriwijaya Kingdom during the $11^{\text {th }}$ Century.

\section{Misconception 2: "The Minangkabau people were the ones that brought the matrilineal customs to Negeri Sembilan."}

With reference to Figure 7, the remarkable degree of consistency between the new settlements opened by the Minangkabau people and the intermarriages with the Biduanda clan leaders' daughters in Table 3 and 4 (Adil, 1981; Gullick, 2003) added to Misconception 2. The ease into which the Jakun communities accepted the intermarriages was a fact that should be brought forth and provoked people to rethink or re-evaluate their belief of 
misconception 2. Adil and Idrus confirmed otherwise as demonstrated in Table 2.

Table2:Comparisontableofthe JakunandMinangkabaucommunitiesatthetime of the majortransmigrations.

\begin{tabular}{|c|c|c|}
\hline $\begin{array}{l}\text { Communities' } \\
\text { people }\end{array}$ & $\begin{array}{l}\text { JAKUN/SAKAlI } \\
\text { BIDUANDA }\end{array}$ & MINANGKABAU \\
\hline Custom & Matrilineal & Matrilineal \\
\hline $\begin{array}{l}\text { Name given to } \\
\text { the custom }\end{array}$ & $\begin{array}{l}\text { None } \\
\text { [Note: 'Adat Perpatilh' } \\
\text { was given after the } \\
\text { assimilation of both } \\
\text { communities' through } \\
\text { intermarriages when the } \\
\text { Jakun became muslims] }\end{array}$ & $\begin{array}{l}\text { Adat Minangkabau divided into } 2 \text { type } \\
\text { (laras) (Idrus. } 1996, \text { p. } 17 \text { ): } \\
\text { Laras Koto-Piliang (lead by Datuk } \\
\text { Perpatih nan Sabatang) } \\
\text { Laras Bodi-Caniage (lead by Datuk } \\
\text { Katamanggungan) }\end{array}$ \\
\hline $\begin{array}{l}\text { Religion' } \\
\text { believe }\end{array}$ & $\begin{array}{l}\text { Nature's spirit (Semangat. } \\
\text { Alaw) }\end{array}$ & Islam \\
\hline Clans & $\begin{array}{l}\text { Did not practice division of } \\
\text { groups within communities } \\
\text { through clans }\end{array}$ & $\begin{array}{l}\text { Practicing division of groups within } \\
\text { communities through clans. }\end{array}$ \\
\hline Leaders & $\begin{array}{l}\text { Community's leader was } \\
\text { called 'Tok Batin'. }\end{array}$ & Clan leaders were given titles. \\
\hline $\begin{array}{l}\text { Female } \\
\text { Leaders }\end{array}$ & $\begin{array}{l}\text { There were female } \\
\text { community's leaders } \\
\text { appointed. } \\
\text { (Example: Batin } \\
\text { Bercangoal Besi is } \\
\text { female.) }\end{array}$ & $\begin{array}{l}\text { Clan leaders are men from the female } \\
\text { lineage. }\end{array}$ \\
\hline
\end{tabular}

Table 3: Intermarriages between the daughters of Biduanda clan leaders with the Minangkabau clan leader

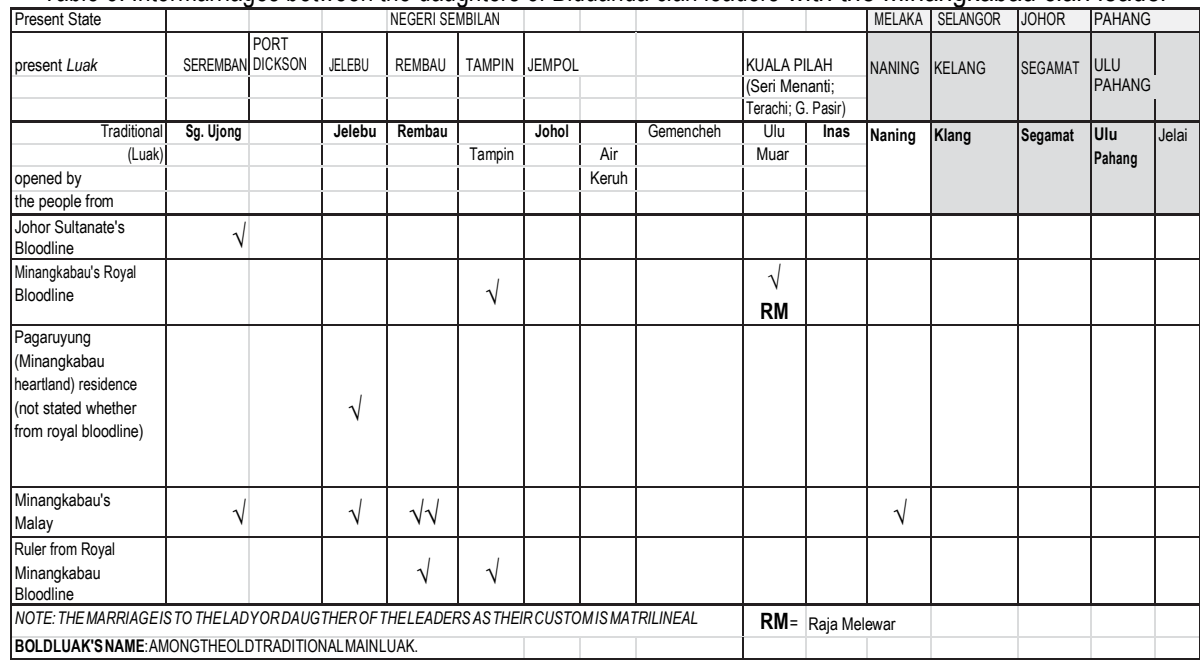


Masri, M., / Asian Journal of Environment-Behaviour Studies (ajE-Bs), 3(8) May / Jun 2018 (p.187-204)

Table 4: Recorded New Settlements opened in the minor states of Negeri Sembilan.

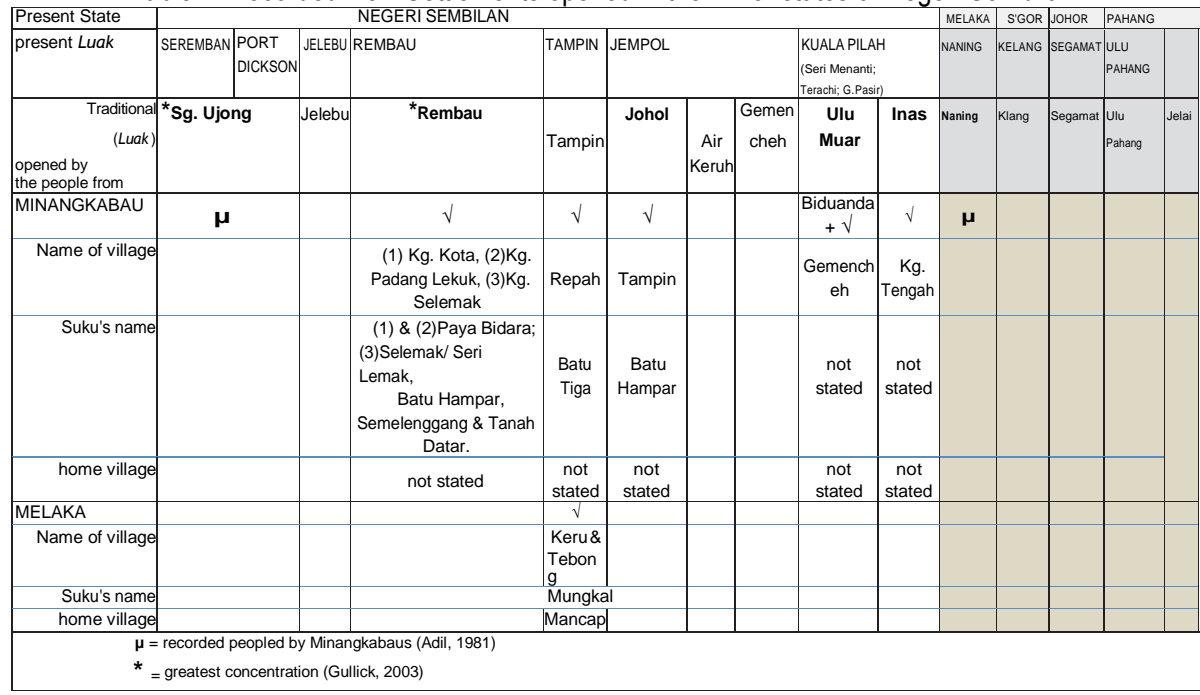

Misconception 3: "The slight upward curves ('lentik') on both ends of the Negeri Sembilan traditional house, is the visual representation of the buffalo horns".

Idrus research however proved that the Negeri Sembilan traditional house's roof shape is the visual representation from the shape of 'Kajang Perahu' and not from the shape of Buffalo horns (Tanduk Kerbau). 'Perahu' is the name given to a type of Malay boats. 'Kajang' means the roof of the rear part of the perahu made from the nipah leaves (DBP, 2012). An unexpected revelation, yet, undeniably fit within the maritime culture of the ancient Malays. Furthermore Waterson wrote that Vroklage (based on his research in 1934) concluded that the curve roofs with their pointed ends symbolized the boats of the bearer's culture. Vroklage even named the curve roof as 'ship roof' to be better signifies the 'true' meaning (Waterson, 2009). Curiously European origin researchers' commonly referred to such curve roof as the 'saddle-back' roof (Waterson, 2009; Oliver, 2006).

Many related research centred more on the Minangkabau association, thus overlooked the Negeri Sembilan association with Siak, a district within the mainland Riau in the Eastern Sumatra (Figure 3). Notably the 'Lontik' roof of Riau is the visual representation of the 'Lancang' (traditional boat) (Idrus, 1996; Nurdiani, 2005), also manifested in the external ornamentations and decorative elements of the house. Chapter 3.5 would further clarify the fact that it is not a visual representation of the buffalo horns.

\section{The Roof Shape}

It is rather peculiar that the Negeri Sembilan house to be called the Minangkabau house when there are obvious differences especially in the shape and form of the roof. Table 6 shows the comparison of the roof shape, however cross reference with Figure 8(a), 8(b) and 
Figure 9 is essential. Any references to interior spaces refer to Chapter 3.6.

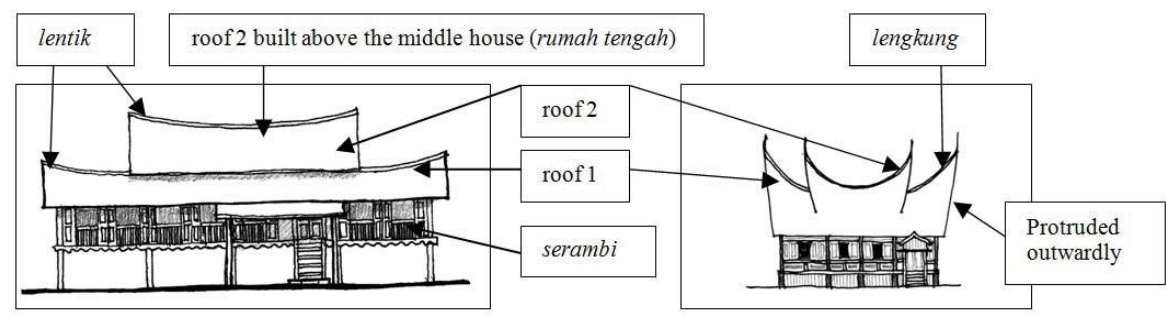

(a)

(b)

Fig. 8: (a) Elevation of Negeri Sembilan Traditional House; (b) Elevation Minangkabau Traditional House

Table 6: Comparison of the characteristics of the roof shapes.

Sketch of a
typical house


7 Roof 2

construction

8 Name given to the long roof construction characteristic

9 Significance of roof layers
Usually built above the 'middle house' which also consist of the attic, two levels! storey spaces. Refer to Figure 10 , blue colour dotted line.

Bumbung 'bertingkat' which means 'levelled' roof.
Constructed on top of roof 1 forming another layer above roof 1. Refer to Figure 11, red colourt dotted line.

Bumbung 'berlapis' which means "layered roof.
The number of roof layers

signifies the importance or status of owner.
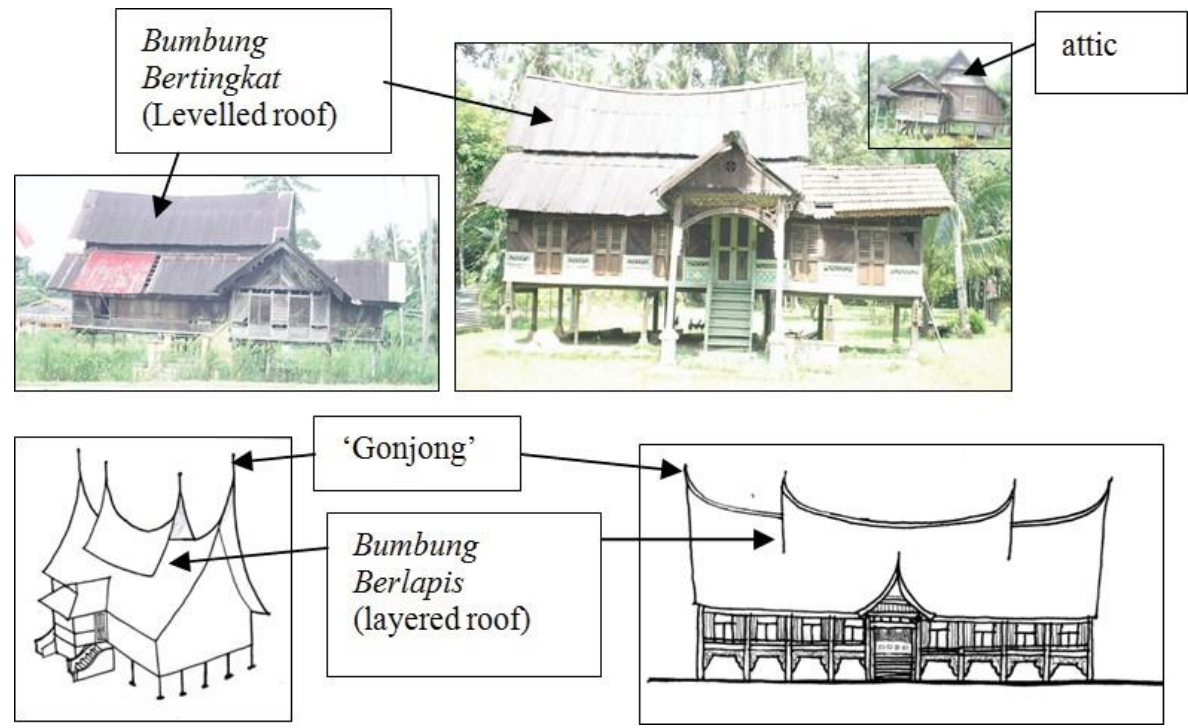

Figure 9: showing the difference between levelled roof and layered roof

Misconception 4: The interior spatial layout of Negeri Sembilan Traditional House is the same as the Minangkabau Traditional House interior spatial layout.

Figure 10(a) shows the basic interior spaces for a typical Negeri Sembilan traditional house whereas Figure 11 and 13 shows the Minangkabau traditional house. 


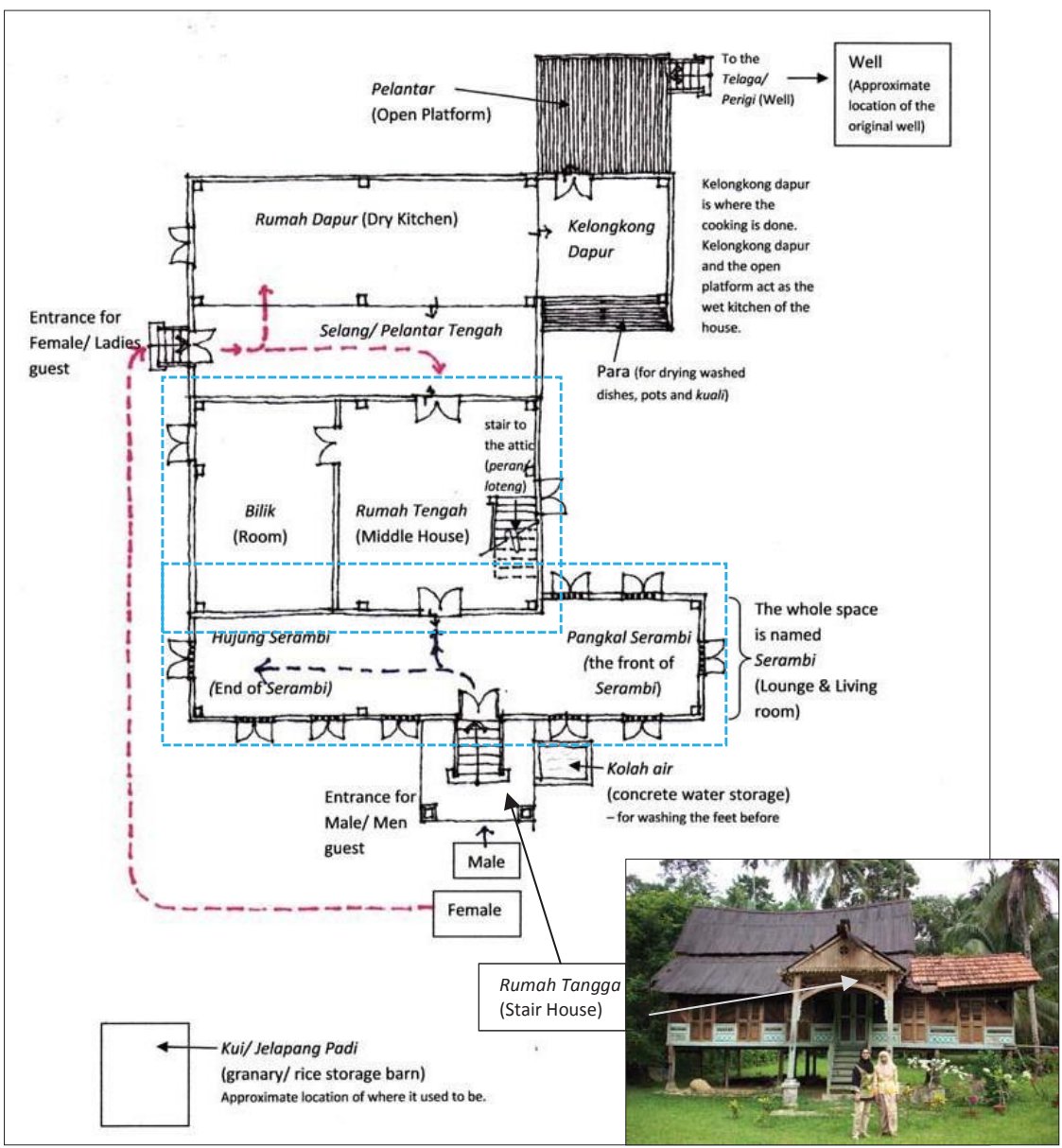

Fig. 10:(a)atypicallayout of NegeriSembilantraditional housetypicallayout housein Kg.Penajeh based onthe presentowner's description. (b) Photograph of the house's façade.

There are obvious differences not only in the spatial arrangement of the hierarchical and functional sequence, how the spaces are defined using walls and floor levels differentiation but also the number and orientation of the entrances. However the Minangkabau traditional houses differ based on the type of custom, the Laras Kato-Piling (K-P) or Laras Bodi-Caniago (B-C). Mainly by the orientation of the entrance, floor levels and spaces built at both of the gable ends as shown Figure 11, 12 and 13. 


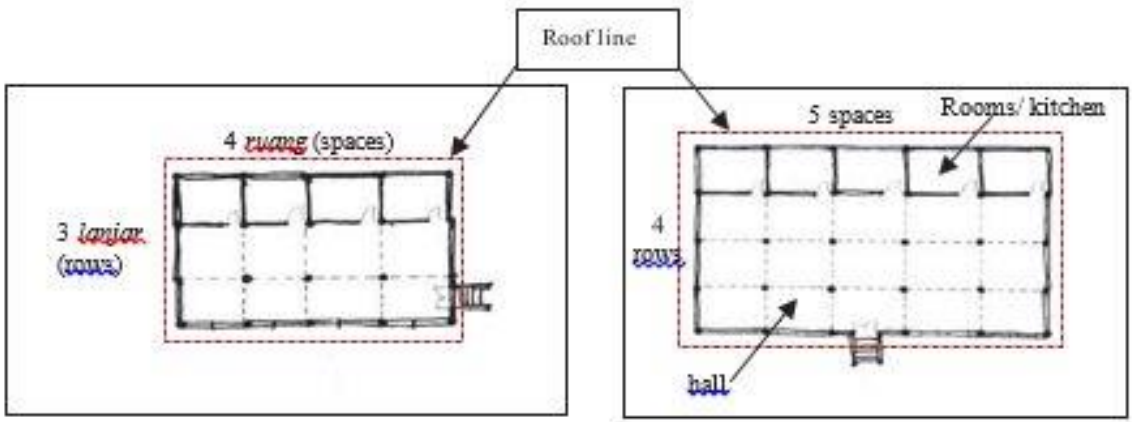

Fig. 11: (a) Minangkabau traditional house type B-C;

(b) Minangkabau traditional house type K-P (adapted from Idrus, 1996).
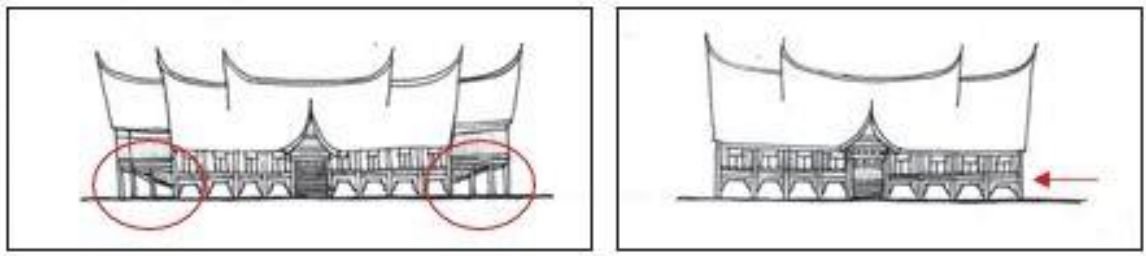

Fig. 12: (a) TypeB-C withindicating the stepped spaces on both ends (Waterson 2009; Aisyah Fajriet. al., 2009; Idrus, 1996); (b) TypeK-P where the floorisall atthe same level (adapted from Idrus).

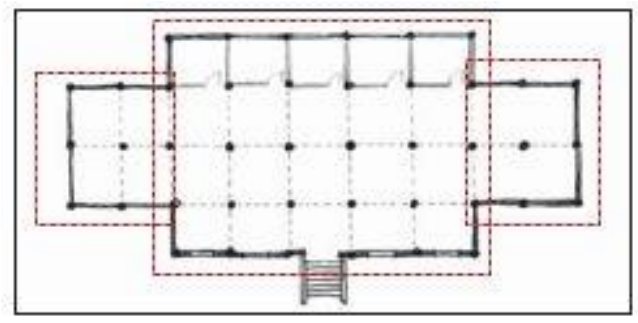

Fig. 13: Typical Minangkabau traditional house type C-B.

In conclusion, the roofs of the Negeri Sembilan traditional houses were built based on the spatial arrangement and hierarchy whereas Minangkabau roof mostly housed the whole of the interior spaces.

\subsection{Survey Indication}

A survey using questionnaires was executed to confirm the findings within an education institutional most related to the built environment. For this paper, only analysis related to the context is presented. The respondents were asked to answer the followings: 
1) To identify from the sketches in Figure 14, best shown the characteristics of Negeri Sembilan roof form. Result in Figure 15(a).

2) To identify the visual representation of the lentik (slight upwards curve) shape of the Negeri Sembilan traditional house. Result in Figure 15(b).

3) To identify the roof construction characteristics of Negeri Sembilan traditional houses whether layered or levelled. Result in Figure 16.

As this paper was written with our future communities in mind, therefore the questionnaires analysis were refined in order to find out the result of respondents with the age of 30 years and below. 202 of 232 respondents were below the age of 30 years old.

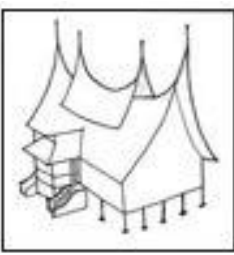

(a)

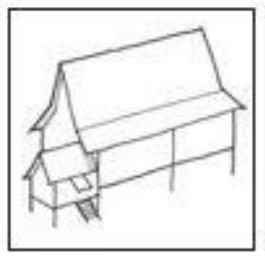

(b)

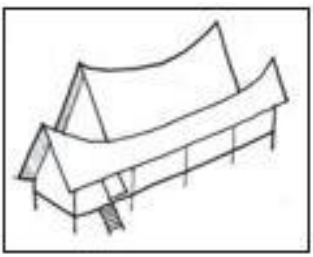

(c)

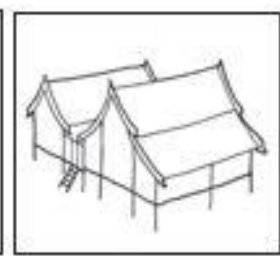

(d)

Figure 14: (a) Minangkabau Traditional House, Western Sumatra; (b) Malay Traditional House in the Northern Region of Malaysia; (c) Negeri Sembilan Traditional House, Malaysia; (d) Malay Traditional House in the Eastern Region of Malaysia. [(b), (c), (d) redrawn from Lim, 1987].

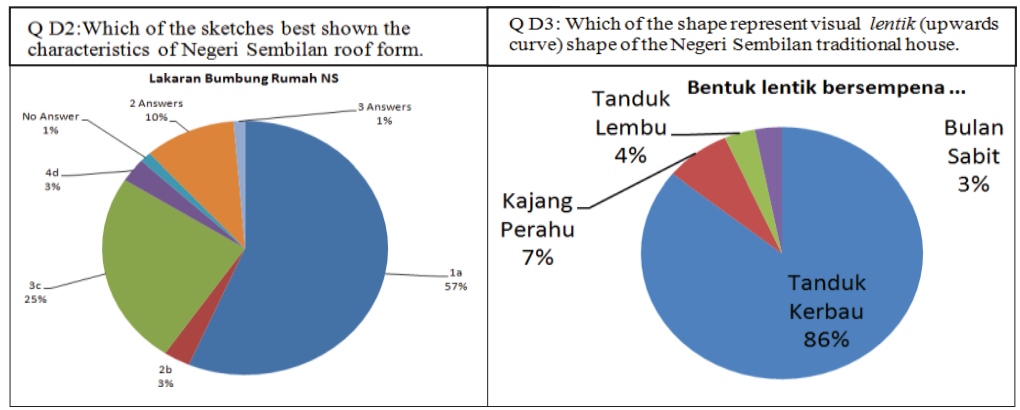

(a)

(b)

Fig. 15: (a) Result of the survey on characteristics of the Negeri Sembilan roof form;

(b) Result of the survey on the visual representation of the roof's upward curves.

The answer for question (i) is Figure 14(c). Figure 15(a) showed that $57 \%$ of the respondent chose the incorrect answer, the Minangkabau house and a disturbingly large percentage, $85.9 \%$ of the $57 \%$ were below 30 years old.

For question (ii) it was found that $84.6 \%$ of the $86 \%$ that answered tanduk kerbau (buffalo 
horns) were below 30 years old. A scarce of $7 \%$ answered 'kajang perahu', and a disturbingly $88.24 \%$ from that are below 30 years old.

In addition to that respondents were asked question (iii). The results are shown in Figure $16(a)$ and (b) relatively. An alarming number of at least $33 \%$ of the respondents were unsure of the answer even when sketches as in Figure 9 were shown in the questionnaire.

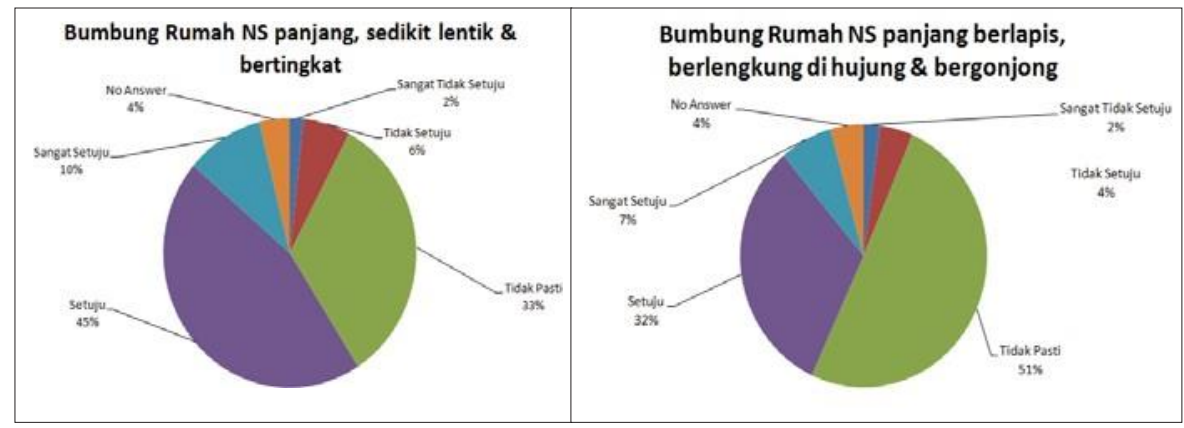

(a)

(b)

Fig. 16: (a) Result of the survey on characteristics of the Negeri Sembilan roof form; (b) Result of the survey on the visual representation of the roof's upward curves.
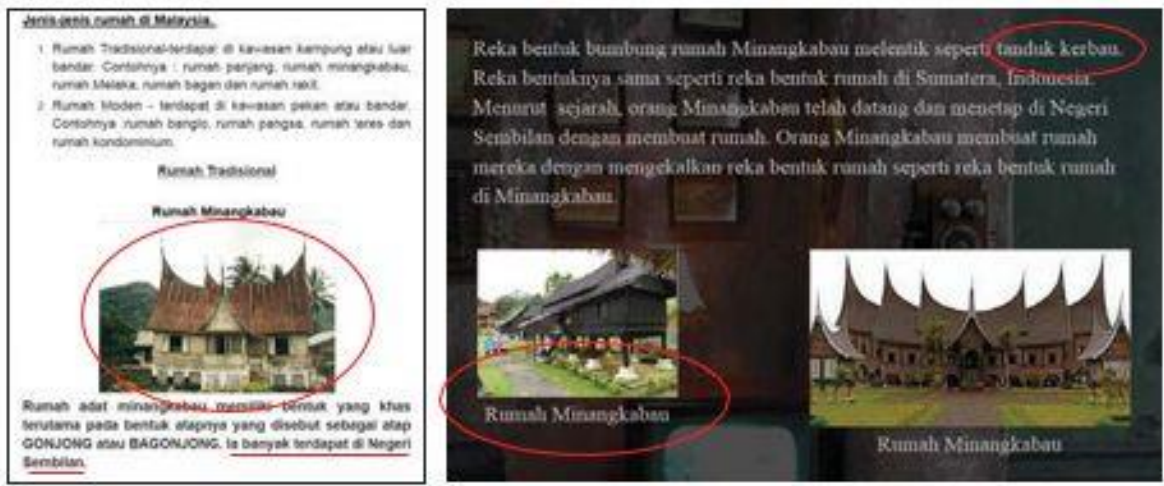

Fig. 17: Examples of misconceptions in blogs

The results of the survey were in accordance to findings of the literature reviews, the existence of misconceptions among the younger generation. However such disturbing results prompted the websites and blogs to be investigated to see the extent of misconceptions within the information shared. The findings were shocking. Figure 17 are examples of assignments for 'Kajian Tempatan: Year 4' subjects.

\subsection{Conclusion}

The presented misconceptions are not meant to deny the presence of the Minangkabau 
origin within the communities but meant to enhance their unique existence that has evolved through time together with the Jakun communities. Although there were echoes of their origins within their architectural language but the integration of both cultures, evolved through time within the maritime cultures, became an outstanding creation independent of their ancestral traditional architectural language in Minangkabau. Unless presented to the world in pride and acknowledged, identity ownership will be gained.

The Negeri Sembilan traditional architecture is the manifestation of the unique hybrid of both cultures. It is not wrong to copy the traditional architecture of Minangkabau and trying to preserve it in Malaysia, similarly to the Chinese copying their ancestral architectural language into their buildings.

In order to avoid future misconceptions, two considerations must be made. One to the hybrid families such as the Biduanda Jawa clans, who would like to brought forth to the world their unique culture although different from Minangkabau but distinctly influenced by it. The other is to the pure descendants of the original Minangkabau clans who intended to preserve their ancestral identity as in Minangkabau. The author recommends that the traditional house to be termed as follows:

1) The Negeri Sembilan Malay traditional house.

2) The Negeri Sembilan Minangkabau traditional house.

Figure 18 (a), (b), (c), and (d) shows the Negeri Sembilan Malay Traditional Houses including additional spaces that reflect the status or rank of the owner within the communities.
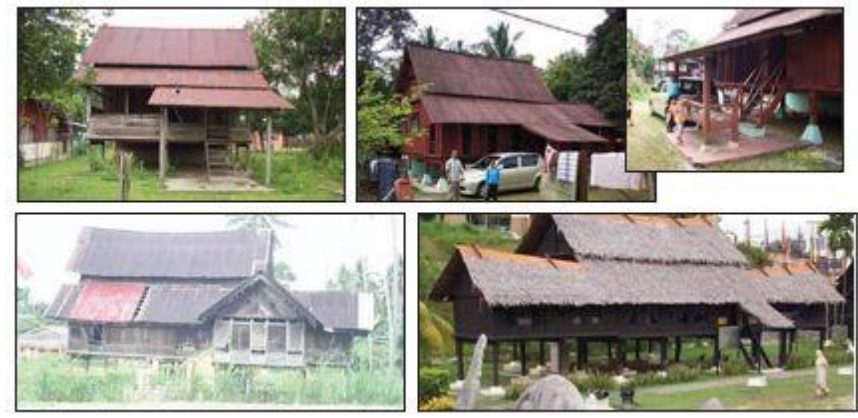

Fig. 18: (a)Ahouse in Kg. Pulau Hanyut, Rembau;(b)house in Kg. Pulau Hanyut withpangkalserambiand Rumah Tanggawithseating platform called'pangkin'; (c) ahouse in Kotatown showing an anjungatthe front; (d) additional spaces to the serambion both gable ends

\section{Acknowledgements}

The author would like to thank the Malaysia's Ministry of Higher Education for funding this research through a grant scheme called Fundamental Research Grant Scheme (FRGS) and the Research Management Institute (RMI) of Universiti Teknologi MARA, Malaysia. 


\section{References}

Adil, H. B. (1981). Sejarah Negeri Sembilan. Kuala Lumpur: Dewan Bahasa dan Pustaka.

DBP. (2008-2012). Pusat Rujukan Persuratan Melayu. Retrieved September 29, 2012, from Dewan Bahasa dan Pustaka: http://prpm. dbp.gov.my/

de Jong, P.(1975). The dynastic myth of Negri Sembilan (Malaya). kiltv- journals.nl, 279-307. Retrieved June 18, 2010, from http://sabrizain. org/malay/library/dynasticmyth.pdf

Gullick, J. (2003). A History of Negri Sembilan. Selangor: Malaysian Branch of Royal Asiatic Society (MBRAS).

Ibrahim, N. (1988). Some Observations on Adat and Adat Leadership in Rembau, Negeri Sembilan. Journal of Southeast Asian Studies, 26/2, 150-165.

Idrus, Y.(1996). Rumah Traditional Negeri Sembilan: Satu Analysis Seni Bina Melayu. Shah Alam, Selangor: Penerbit Fajar Bakti Sdn. Bhd.

Kato, T. (1997, March). Dynamics of the Frontier World in Insular Southeast Asia: An Overview. Southeast Asian Studies, 34(No. 4), 611-621.

Lim, J. Y. (1987). The Malay House. Pulau Pinang: Institut Masyarakat. Loeb, E. (1989). Sumatra: Its History and People. Singapore: Oxford

University Press.

Masri, M., Samadi, Z., Aziz, A. (2012a). Conflict of Ownership and Identity between Negeri Sembilan and Minangkabau: A Review of the Literature. In H. Pulhan (Ed.), 6th International Seminar on Vernacular Settlements 2012 - Contemporary Vernaculars: Places Processes and Manifestations (ISVS-6). II, pp. 515-526. Famagusta, North Cyprus, Turkey: Eastern Mediterranean University.

Mursib, G., Mohammad, R. (2005). The Malay house of the Peninsula west coast. In V.F. Chen, The Encyclopedia of Malaysia: Architecture (pp. 24-25). Kuala Lumpur: Archipelago Press.

Nasir, A. H.(1985). Pengenalan Rumah Tradisional Melayu Semenanjung Malaysia. Kuala Lumpur: Darul Fikir.

Nurdiani, N. (2005). Architectural Elements of Malay Traditional House In Indo-Malayan Region. International Seminar Malay Architecture As Lingua Franca (pp. 79-85). Jakarta, Indonesia: TrisaktiUniversity.

Waterson, R. (2009). The Living House: An Anthropology of Architecture in South-East Asia. Singapore: Turtle Publishing.

Waterson, R. (2005). The Austronesian house: Contemporary models. In

V.F.Chen, The Encyclopedia of Malaysia: Architecture (pp. 16-17). Kuala Lumpur: Archipelago Press. 